\title{
EVALUASI KELAYAKAN INVESTASI PROYEK PEMBANGUNAN PERUMAHAN GREEN TERRACE DITINJAU PADA ASPEK KEUANGAN
}

\author{
Amin Ilyas \\ UniSadhuGuna Business School \\ Email: amin.ilyas@ubs-usg.ac.id
}

\begin{abstract}
Abstrak
Pendahuluan : Tingkat pertumbuhan penduduk Indonesia cukup tinggi terutama di wilayah Jabodetabek (Jakarta, Bogor, Depok, Tangerang, Bekasi). Hal ini mengakibatkan meningkatnya permintaan untuk rumah. Proyek Perumahan Green Terrace yang berlokasi di jalan Mukti, Jati Asih, Bekasi, yang selesai dibangun pada tahun 2013, berkontribusi terhadap peningkatan permintaan rumah.

Tujuan : Pembiayaan proyek adalah informasi yang dapat membantu investor untuk mengidentifikasi kelayakan suatu proyek. Salah satu alat yang digunakan dalam analisis keuangan adalah penganggaran modal.

Metode : Dengan metode perhitungan menggunakan NPV, IRR, dan PI. Peneliti menggunakan data sekunder dari PT Ritma Panca Gemilang, dalam bentuk arus kas selama proyek dalam jangka waktu tertentu, dari 2009 hingga 2013.

Hasil : Hasil penelitian ditinjau pada aspek keuangan melalui metode perhitungan Net Present Value (NPV), Internal Rate of Return (IRR), dan Profitability Index (PI). Hasil perhitungan Ketiga menunjukkan hasil yang baik, sehingga evaluasi penganggaran modal pembangunan perumahan Green Terrace layak. Hasil penelitian ditinjau melalui aspek keuangan metode penganggaran modal memunculkan Net Present Value (NPV) Rp 7.286.398.008,25, Internal Rate of Return (IRR) dengan persentase 25\%, dan Profitability Index (PI) 2,86.

Kesimpulan : Hasil perhitungan menunjukkan hasil yang ideal, sehingga evaluasi penganggaran modal pembangunan perumahan Green Terrace prope.
\end{abstract}

Kata kunci : Studi Kelayakan; Penganggaran Modal

\section{Abstract}

Introduction: Indonesia's population growth rate is quite high, especially in jabodetabek (Jakarta, Bogor, Depok, Tangerang, Bekasi). This has led to increased demand for homes. Green Terrace Housing Project located on Mukti street, Jati Asih, Bekasi, which was completed in 2013, contributed to the increase in demand for homes.

Objective: Project financing is information that can help investors to identify the feasibility of a project. One of the tools used in financial analysis is capital budgeting.

Method: With calculation methods using NPV, IRR, and PI. Researchers used secondary data from PT Ritma Panca Gemilang, in the form of cash flow during the project within a certain period of time, from 2009 to 2013.

Results: The results of the study are reviewed on financial aspects through the method of calculating Net Present Value (NPV), Internal Rate of Return (IRR), and Profitability Index (PI). The results of the Third calculation showed good results, so the evaluation of capital budgeting of green terrace housing development is feasible. The results of the study reviewed through the financial 
aspects of capital budgeting methods gave rise to Net Present Value (NPV) of Rp 7,286,398,008.25, Internal Rate of Return (IRR) with a percentage of $25 \%$, and Profitability Index (PI) of 2.86.

Conclusion: The results of the calculation showed ideal results, so that the evaluation of capital budgeting of green terrace prope housing development.

\section{Keywords : Feasibility Study; Capital Budgeting}

\section{Pendahuluan}

Pada masa lalu, rumah berfungsi sebagai tempat berlindung untuk mendapatkan keamanan dan kenyamanan, terhindar dari cuaca buruk, hewan buas, serta tempat beristirahat. Tetapi sekarang ini definisi rumah telah meluas. Rumah, apalagi yang berada di pusat kota merupakan sumber investasi yang aman selain daripada fungsi utamanya tempat tinggal (Dewi \& Darma, 2019). Saat ini banyak rumah yang dibeli lalu disewakan dalam jangka waktu tertentu atau bahkan dijual kembali dengan harga yang jauh lebih tinggi dan semakin meningkat (Hidayat, 2014). Peningkatan investasi properti mulai terlihat secara fisik di kota-kota besar seperti Jakarta, Bandung, Yogyakarta, Surabaya dan Medan.

Berdasarkan pemaparan (Santoso, 2019) pengembangan kawasan pusat perbelanjaan, apartemen dan perumahan gencar dilakukan pihak developer, untuk mengikuti pertumbuhan permintaan pasar diiringi semakin membaiknya daya beli masyarakat. Berinvestasi di sektor properti selain berpeluang untuk dapat memperoleh keuntungan dari apresiasi atau peningkatan nilai jual properti, kita juga dapat menikmati keuntungan dari penyewaan properti yang bersangkutan (Putri, 2016). Berinvestasi dengan membeli properti rumah tinggal yang memiliki harga sewa dan nilai jual yang tinggi dapat menguntungkan sepanjang permintaan pasar sewa rumah tinggal di daerah tersebut masih cukup tinggi dan terjamin tidak ada faktor-faktor yang dapat menurunkan nilai jual dan tingkat harga sewa properti rumah tinggal tersebut (Arifin, 2011).

Menurut Senior Associate Director Research and Advisory Cushman and Wakefield Indonesia, Arief N. Rahardjo, Tangerang dan Bekasi merupakan dua kawasan yang paling aktif dalam pembangunan properti, terutama perumahan, ketimbang kawasan lainnya di Jadebotabek (Fardiansyah, 2017). Pasokan hunian selama semester satu 2014, didominasi kedua kawasan tersebut, masing-masing Tangerang sebanyak 53 persen atau 2.430 unit dari total pasokan 9.283 unit. Sementara Bekasi memasok rumah baru sebanyak 268 unit yang berasal dari tiga perumahan yakni kota Jababeka, kota Harapan Indah, dan Lippo Cikarang. Secara kumulatif, Bekasi di tempat kedua sebanyak 25 persen dengan angka 81.691 unit dibawah Tangerang. Harga rumah di kawasan bekasi dengan populasi sekitar 6 juta jiwa terus mengalami lonjakan tiap tahun, rata-rata 9 persen selama enam bulan pertama 2014. Sementara Tangerang hanya 7 persen. Bekasi juga unggul dalam hal kenaikan harga tanah yakni sebesar 15 persen. Lonjakan harga tanah ini terjadi di perumahan utama seperti Summarecon Bekasi yang saat ini dibanderol seharga Rp 9 juta per meter persegi untuk lahan hunian. Sedangkan Tangerang hanya mencatat pertumbuhan harga tanah sekitar 6 persen. Harga lahan tertinggi saat ini ada di kawasan Alam Sutera yakni berkisar antara Rp 10 juta hingga Rp 15 juta per meter persegi.

Menurut (Mahardini \& Woyanti, 2012) keadaan tersebut mencerminkan tingkat permintaan yang cukup tinggi, tentu hal ini tidak disia-siakan oleh banyak investor lokal 
untuk melakukan investasi membangun perumahan. Berdasarkan (Dengah, Rumate, \& Niode, 2014) dalam melakukan investasi tersebut perlu diperhatikan beberapa aspek penunjang usaha untuk mendapatkan laba yang optimal dan untuk mengetahui apakah usaha tersebut layak atau tidak melalui aspek-aspek tertentu (Arishandi, 2015). Dalam penelitian ini, penulis fokus menggunakan aspek keuangan sebagai tolak ukur kelayakan. Dalam suatu proyek investasi pembangunan properti peruhaman umumnya memiliki batas waktu artinya proyek harus diselesaikan sebelum atau tepat pada waktu yang telah ditentukan. Hal ini berkaitan dengan kepuasan konsumen, modal kerja dan biaya operasional yang digunakan selama pembangunan (Harahap, 2013).

Pembangunan yang semakin lama tentu memakan biaya lebih banyak, apalagi jika melewati batas yang telah ditetapkan di awal rencana kerja. Berkaitan dengan masalah hal tersebut maka optimalisasi keuangan dalam hal ini modal kerja penting untuk diperhitungkan dan direncanakan secara matang. Yang pada akhirnya pelaksanaan sebuah proyek pembangunan, terselesakan tepat pada waktunya dengan modal yang sesuai perhitungan awal, apalagi bila bisa ditekan menjadi lebih kecil. Demi kelancaran jalannya sebuah proyek dibutuhkan perencanaan keuangan yang matang, sehingga investasi perusahaan berjalan lancar dan menguntungkan (Triyani, 2003). Investasi merupakan hal yang penting bagi perusahaan karena dengan melakukan investasi perusahaan mampu meningkatkan profit serta pada akhirnya turut membantu mensejahterakan para pegawai dan pemilik perusahaan (Lestari, 2012).

Seperti telah disebutkan diatas, penelitian hanya fokus pada aspek keuangan yang mengedepankan nilai profit dari suatu proyek, kriteria penilaian investasi layak atau tidaknya melalui metode penganggaran modal (Capital Budgeting) ada banyak metode didalamnya, namun peniliti hanya menggunanakan tiga metode yakni Profitability Index (PI) merupakan rasio nilai sekarang arus kas bersih proyek dimasa depan terhadap arus keluar kas awal; Net Present Value (NPV) metode yang menghitung selisih antara nilai sekarang investasi dengan nilai sekarang penerimaan-penerimaan kas bersih dimasa yang akan datang; dan Internal Rate of Return (IRR) metode yang menghitung tingkat bunga yang menyamakan nilai sekarang investasi dengan nilai sekarang penerimaan-penerimaan kas bersih dimasa yang akan datang.

Tujuan dari penelitian ini adalah untuk mengetahui evaluasi dari proyek investasi pembangunan perumahan Green Terrace ditinjau dari aspek keuangan. Menggunakan metode capital budgeting (studi kelayakan), melalui perhitungan;

a. IRR (Internal Rate of Return)

b. NPV (Net Present Value)

c. PI (Profitability Index)

Harapannya dengan mengetahui ketiga hal tersebut penulis dan perusahaan dapat mengetahui hasil yang tepat bilamana metode capital budgeting diterapkan pada proyek tersebut. Dengan diketahui hasil perhitungan tersebut, secara tidak langsung penulis akan mengetahui optimalisasi apa yang dilakukan perusahaan dalam rangka menekan biaya investasi sehingga perusahaan mendapatkan keuntungan berlipat ganda

\section{Metode Penelitian}

Dalam penelitian ini menggunakan jenis penelitian deskriptif dengan metode kualitatif (Sugiyono, 2012). Menurut (Sunyoto \& Admojo, 2014) penelitian deskriptif 
yaitu tipe penelitian yang bertujuan untuk mendreskripsikan tentang fenomena sosial tertentu termasuk tentang hubungan kegiatan, sikap, pandangan, serta proses yang sedang berlangsung dan pengaruh dari suatu fenomena secara terperinci. Penelitian deskriptif menurut (Soendari, 2012) bersifat paparan ditujukan untuk mendreskripsikan masalah-masalah dalam penelitian.

Sumber data yang diperoleh bersifat data sekunder, yaitu data penelitian yang didapat secara tidak langsung dan teknik pengumpulan data dilakukan melalui studi literatur dengan membaca dan memahami literatur, buku, karya ilmiah, yang berhubungan dengan masalah yang akan di teliti. Tujuan dari kegiatan studi literatur ini adalah untuk mendapatkan konsep-konsep teoritis mengenai masalah-masalah yang relevan dengan masalah yang akan dibahas.

\section{Hasil dan Pembahasan}

Pengambilan secondary data berupa laporan arus kas 5 tahun kebelakang, data keuangan hasil penjualan, dan proyeksi keuangan awal proyek didapatkan tabel sebagai berikut.

Tabel 1

Arus Kas Pembangunan Perumahan

\begin{tabular}{|c|c|c|c|c|c|c|}
\hline & 2009 & 2010 & 2011 & 2012 & 2013 & Total \\
\hline \multicolumn{7}{|l|}{ Arus Kas Mlasuk } \\
\hline Penjualan & & $2440.0000000,0$ & $5.368 .000 .000,0$ & 7.381.000.000,0 & $8.119 .100 .000,0$ & $23.308 .100 .000,0$ \\
\hline Total Penerimaan & & $2.440 .000 .000,0$ & $5.368 .000 .000,0$ & $7.381 .000 .000,0$ & $8.119 .100 .000,0$ & $23308.100 .000,0$ \\
\hline \multicolumn{7}{|l|}{ Arus Kas Keluar } \\
\hline Perijinan dan Perencenaan & $345.000 .000,0$ & & & & & $345.000 .000,0$ \\
\hline Inventaris (xalatan, pritengkapan) & $50.000 .000,0$ & & & & & $50.000 .000,0$ \\
\hline Infrastruktur & $1.0325000 .000,0$ & & & & & $1.0325000 .000,0$ \\
\hline Baya Tanah & $500.000 .000,0$ & $357.5000000,0$ & $715.000 .000,0$ & $893.750 .000,0$ & $899.750 .000,0$ & $3.360 .000 .000,0$ \\
\hline Pembangunan Rumah & $350.000 .000,0$ & $700.000 .000,0$ & $1.877 .500 .000,0$ & $2315.250 .000,0$ & $810.337 .500,0$ & $6.013 .087 .500,0$ \\
\hline Pemasaran & & $61.000 .000,0$ & 1342000000,0 & $184.525 .000,0$ & $202.977 .500,0$ & $582.702 .500,0$ \\
\hline Biaya Kantor & $50.000 .000,0$ & $72.000 .000,0$ & $79.200 .000,0$ & $87.120 .000,0$ & $95.832 .000,0$ & $384.152 .000,0$ \\
\hline Transpottasi & $8.500 .000,0$ & $9.350000,0$ & $10285.000,0$ & $11313.500,0$ & $12.44 .850,0$ & $51.893 .350,0$ \\
\hline Biaya Bunga & $132.000 .000,0$ & $264.000 .000,0$ & $204.000 .0000,0$ & $24.000 .000,0$ & & $624.000 .000,0$ \\
\hline Cicilan Hutang & & $500.0000000,0$ & $1.500 .000 .000,0$ & $200.000 .000,0$ & & $22000.000 .000,0$ \\
\hline Total Arus Ka Operasional Keluar & $2.468 .000 .000,0$ & $1.963 .850 .000,0$ & $4.480 .185 .000,0$ & $3.715 .958 .500,0$ & $2.015341 .850,0$ & $14.643 .3355 .350,0$ \\
\hline Selisih Kas Operasional & $(2.468 .000 .000,0)$ & $476.150 .000,0$ & $887.815 .000,0$ & $3.665 .041 .500,0$ & $6.103 .758 .150,0$ & $8.664 .764 .650,0$ \\
\hline \multicolumn{7}{|l|}{ Sumber Pendanan } \\
\hline Modal Sendiif & $350.000 .000,0$ & & & & & \\
\hline Bank, pembiyan Infra-struktur & $2200.000 .000,0$ & & . & & & \\
\hline \multicolumn{7}{|l|}{ Bank, Pembiayyan KPR } \\
\hline Saldo Kas Awral & $2550.000 .000,0$ & $82.000 .000,0$ & $558.150 .000,0$ & $1.455 .565 .000,0$ & $5.111 .006 .500,0$ & \\
\hline Saldo Kas Akhir & $82.000 .000,0$ & $558.150 .000,0$ & $1.445 .965 .000,0$ & $5.111 .006 .500,0$ & $11.214 .764 .650,0$ & \\
\hline Suku Bunga per tahun & $12,0 \%$ & & & & & \\
\hline Baya Bunga & $132000.000,0$ & $264.0000000,0$ & $204.000 .000,0$ & $24.000 .000,0$ & & $624.000 .000,0$ \\
\hline Pencairan & $2200.000 .000,0$ & & & & & $2200.000 .000,0$ \\
\hline Ciclan Hutang & & $500.0000000,0$ & $1.500 .000 .000,0$ & $200.000 .000,0$ & & $22000.000 .000,0$ \\
\hline gansAPAX & $22000000.000,0$ & $1.700 .00000000,0$ & $200.000 .0000,0$ & & & \\
\hline
\end{tabular}

Untuk menganalisa investasi dengan metode Net Present Value yaitu dengan memperhitungkan bunga deposito (Opportunity Cost) bank dalam hal ini 
bank BTN kurang lebih sebesar 4\% pada tahun 2009 lalu. Arus kas diambil dari saldo kas akhir pada tabel 1 Dengan umur investasi 4 tahun. Dengan hasil perhitungan sebagai berikut:

Tabel 2

\section{Hasil perhitungan NPV dengan suku bunga deposito $4 \%$}

\begin{tabular}{|c|r|c|c|}
\hline Tahun & \multicolumn{1}{c|}{ Casf flow } & 0,04 & PV \\
\hline 0 & $(2.468 .000 .000)$ & 1,0000 & $(2.468 .000 .000,00)$ \\
\hline 1 & 476.150 .000 & 0,9615 & $457.836 .538,46$ \\
\hline 2 & 887.815 .000 & 0,9246 & $820.834 .874,26$ \\
\hline 3 & 3.665 .041 .500 & 0,8890 & $3.258 .208 .547,88$ \\
\hline 4 & 6.103 .758 .150 & 0,8548 & $5.217 .518 .047,65$ \\
\hline & & NPV & $\mathbf{7 . 2 8 6 . 3 9 8 . 0 0 8 , 2 5}$ \\
\hline & & \multicolumn{3}{|c|}{ Sumber: Penulis, 2015 } \\
\hline
\end{tabular}

Net Present Value proyek ini dengan Discount Factor 4\%/ tahun adalah Rp. 7.286.398.008,25 sehingga proyek ini layak karena nilai sekarang (present value) dari aliran kas bersih masa mendatang bernilai positif.

b. Perhitungan IRR

Untuk menghitung Internal Rate of Return, terlebih dahulu harus menghitung net present value secara trial and error. Dalam hal ini karena telah didapatkan hasil perhitungan net present valueyang positif yaitu sebesar Rp. 7.286.398.008,25. Angka tersebut digunakan sebagai net present value satu (NPV1) dari perhitungan dengan tingkat suku bunga4\%, selanjutnyamaka digunakan tingkat suku bunga 30\% dengan umur investasi 4 tahun untuk mencari net presen value dua (NPV 2) yang negatif dari Cashflow sebagai berikut :

Tabel 3

Perhitungan NPV ke 2

\begin{tabular}{|r|r|c|r|}
\hline Tahun & \multicolumn{1}{|c|}{ Casf flow } & \multicolumn{1}{c|}{$\mathbf{1 , 3}$} & \multicolumn{1}{c|}{ PV } \\
\hline 0 & $(2.468 .000 .000)$ & 1,0000 & $(2.468 .000 .000,00)$ \\
\hline 1 & 476.150 .000 & 0,7692 & $366.269 .230,77$ \\
\hline 2 & 887.815 .000 & 0,5917 & $525.334 .319,53$ \\
\hline 3 & 3.665 .041 .500 & 0,4552 & $1.668 .202 .776,51$ \\
\hline 4 & 6.103 .758 .150 & 0,3501 & $2.137 .095 .392,32$ \\
\hline & & NPV2 & $\mathbf{( 3 2 1 . 0 9 8 . 2 8 0 , 8 7}$ \\
\hline
\end{tabular}

$$
\begin{aligned}
\text { IRR } & =P I-C I X=\frac{P 2-P 1}{C 2-C 1} \\
& =4 \%-7.286 .398 .008,25 \times 30 \%-4 \% \\
& =-321.098 .280,87-7.006 .151 .931,01
\end{aligned}
$$

Setelah di hitung perhitungan IRR didapat hasil sebesar $25 \%$. Bila di bandingkan dengan bunga deposito pada tahun awa proyek dimulai 2009 sebesar $4 \%$, maka dengan ini dapat di simpulkan bahwa investasi pembangunan ruko ini 
layak di laksanakan dimana $25 \%>4 \%$. Persentase $4 \%$ merupakan perkiraan suku bunga deposito bank BTN pada tahun 2009.

c. Perhitungan PI

Untuk menganalisis investasi dengan Metode Profitability Index, akan dihitung perbandingan antara present value dari penerimaan (cashflow) dengan present value dari investasi.

$\begin{array}{lcc} & & 7.286 .398 .008 \\ & & 2.550 .000 .000 \\ & & \\ \mathrm{PI}= & 2,857410984 \\ \mathrm{PI} & = & 2,86\end{array}$

Hasil perhitungan Profitability Index dari proyek ini adalah sebesar 2,86. Angka tersebut lebih besar dari nilai 1 yang ditetapkan, sehingga dapat disimpulkan bahwa proyek ini sangat layak untuk dilaksanakan.

Perusahaan sebelumnya juga telah membuat proyeksi awal keuangan tanpa memasukkan unsur capital budgeting yang umum dipelajari. Dalam proyeksi tersebut diharapkan keuntungan sebesar Rp 7.592.100.000 dengan asumsi RPG mendapatkan 65\% RP 4.934.865.000 dan Pemilik Tanah 35\% sebesar Rp 2.657.235.000. Hasil ini tidak berbeda jauh dengan perhitungan capital budgeting penulis.

Dari hasil perhitungan pada bagian 4, jelas terlihat bahwa hasil NPV positif, tercermin bahwa perusahaan menghasilkan keuntungan yang cukup tinggi sebesar RP 7.286.398.008,25. Diikuti nilai IRR 25\%, persentase tersebut lebih besar dari suku bunga deposito yang di tetapkan sebesar $4 \%$. Terakhir pada Profitability index dengan hasil 2,86 angka tersebut melebihi 1. sebagai syarat proyek layak dijalankan. Ketiga hasil perhitungan menunjukkan hasil yang positif dan sesuai dengan syarat kelayakan suatu proyek. 


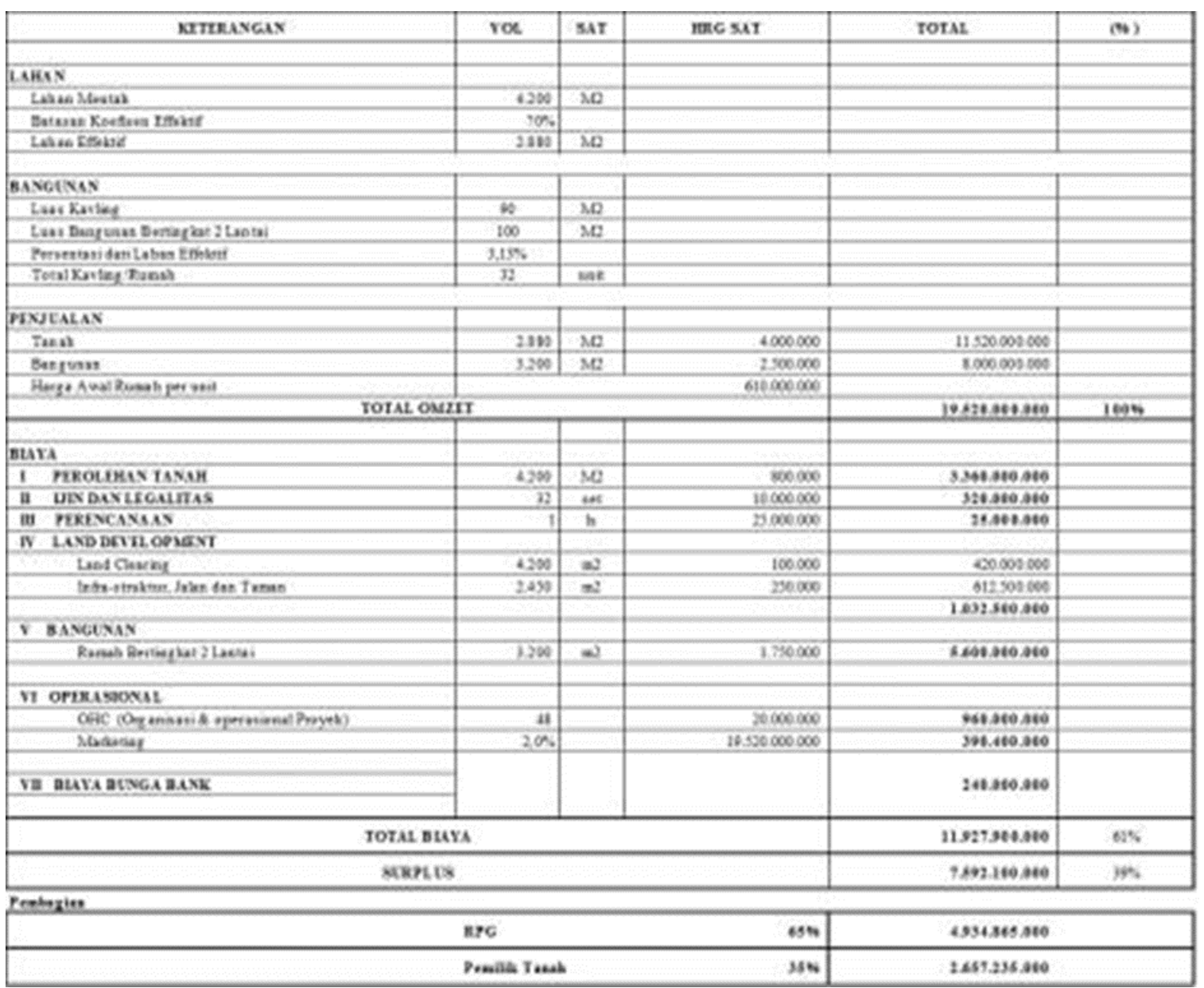

Bila di bandingkan dengan proyeksi awal perusahaan,dengan evaluasi yang peneliti lakukan hasilnya cukup menarik. Dimana proyeksi awal perusahaan yang tidak menggunakan metode capital budgeting hanya mendapat surplus sebanyak Rp 7.592.100.000 sedan peneliti mendapat hasil NPV RP 7.286.398.008,25. Antara proyeksi dengan hasil capital budgeting tidak berbeda jauh, namun pada hasil real didapatkeuntungan Rp. 11.214.764.650,0. Ini berarti perusahaan dalam usahanya selama masa proyek berlangsung telah mengoptimalkan berbagai kemungkinan untuk mendapat profit yang tinggi.

Hasil proyek dan capital budgeting umumnya digunakan sebagai tolak ukur keuntungan/ kerugian yang akan diperoleh di masa depan, pada akhirnya usaha dan kerja keras perusahaan yang akan menentukan hasil akhir pendapatan dari proyek tersebut. Salah satu contoh sederhana yakni dengan bekerja sama melalui bank dan tuan tanah untuk meminimalkan pengeluaran, dengan mengoptimalkan berbagai bentuk perjanjian antara lain, tanah yang belum berpindah tangan ke perusahaan dijaminkan kepada lembaga keuangan dalam hal ini bank, dengan imbalan tuan tanah akan mendapat bagi hasil di akhir masa proyek sebesar 35\% dari keuntungan bersih selain pembayaran akan tanah yang dibeli perusahaan untuk membangun perumahan.

\section{Kesimpulan}


Penelitian ini memperoleh kesimpulan bahwa hasil perhitungan menggunakan Net Present Value berjumlah RP 7.286.398.008,25. Angka tersebut menunjukkan hasil positif dan sesuai dengan syarat kelayakan investasi. Internal Rate of Return sebesar 25\%. Persentase tersebut melebihi bunga deposito rata-rata tahun 2009 sebesar 4\%. Peneliti menyimpulkan bahwa perusahaan akan jauh lebih menguntungkan untuk mengolah modal usaha melalui proyek pembangunan perumahan Green Terrace. Dibanding menaruh modal tersebut di bank sebagai deposito. Profitability Index dengan perolehan 2,86. Dengan angka tersebut peneliti menyimpulkan bawah rasio/ perbandingan net present value dengan modal usaha sangat layak dikarenakan nilainya melebihi 1 sesuai yang di syaratkan dalam rumus perhitungan profilatability index. Peneliti menyimpulkan bawah semakin tinggi dan semakin optimalnya perusahaan menggunakan dana dalam biaya operasional akan menunjukkan peningkatan yang semakin tinggi pada nominal profitability index.

\section{DAFTAR PUSTAKA}

Arifin, Muhammad Yani. (2011). Analisis Tingkat Kapitalisasi Nilai Properti Perumahan Di Kabupaten Klaten. UNS (Sebelas Maret University).

Arishandi, Aldy. (2015). Pemilihan Prioritas Aspek Penunjang Keberlanjutan Usaha 
Pada Industri Kreatif Kerajinan Daur Ulang Kertas Koran Dengan Metode Ahp (Studi Kasus: Cv. Bina Usaha Mandiri). Universitas Muhammadiyah Surakarta.

Dengah, Stefandy, Rumate, Vecky, \& Niode, Audie. (2014). Analisis Pengaruh Pendapatan Perkapita dan Jumlah Penduduk terhadap Permintaan Perumahan Kota Manado Tahun 2003-2012. Jurnal Berkala Ilmiah Efisiensi, 14(3).

Dewi, Ni Ketut Yunita Wulan, \& Darma, Gede Sri. (2019). Strategi Investasi \& Manajemen Resiko Rumah Sakit Swasta di Bali. Jurnal Manajemen Bisnis, 16(2), 110-127.

Fardiansyah, Didi. (2017). Analisa preferensi, motivasi dan persepsi masyarakat dalam menghuni apartemen di Kota Bekasi. Jakarta: Fakultas Ekonomi dan Bisnis UIN Syarif Hidayatullah Jakarta.

Harahap, Fitri Ramdhani. (2013). Dampak urbanisasi bagi perkembangan kota di Indonesia.

Hidayat, Rony Wahyu. (2014). Peluang dan Tantangan Investasi Properti di Indonesia. Jurnal Akuntansi UNESA, 2(2), 1-18.

Lestari, Suci Ayu. (2012). Analisis Pengaruh Modal Kerja Dan Aset Tetap Terhadap Profitabilitas PT. XYZ Periode 2007-2010. STIE Indonesia Banking School.

Mahardini, Ismi, \& Woyanti, Nenik. (2012). Analisis Pengaruh Harga, Pendapatan, Lokasi, Dan Fasilitas Terhadap Permintaan Rumah Sederhana (Studi Kasus Perumahan Puri Dinar Mas Semarang). Diponegoro Journal of Economics, 1(1), 14-24.

Putri, Della Affesia. (2016). Pengambilan Keputusan Konsumen untuk Berinvestasi pada Apartemen dan Perumahan di Surabaya Timur. Institut Teknologi Sepuluh Nopember.

Santoso, Edwin. (2019). Small Stock Big Profit. Elex Media Komputindo.

Soendari, Tjutju. (2012). Metode Penelitian Deskriptif. Bandung, UPI. Stuss, Magdalena \& Herdan, Agnieszka, 17.

Sugiyono. (2012). Memahami Penelitian Kualitatif. Bandung: CV. Alfabeta.

Sunyoto, Danang, \& Admojo, Tri. (2014). Konsep dasar riset pemasaran dan perilaku konsumen.

Triyani, Lelly. (2003). Analisis faktor-faktor yang mempengaruhi tingkat investasi sektor properti di Jawa Tengah tahun 1982-2001. 